\title{
How to tackle revisions of large genera: lessons from Macaranga and Mallotus (Euphorbiaceae)
}

\author{
P.C. van Welzen ${ }^{1}$, K.K.M. Kulju¹, S.E.C. Sierra ${ }^{1}$
}

Key words

Euphoriaceae

Macaranga

Mallotus

phylogeny

revision

species rich genera

\begin{abstract}
Two approaches to revise large genera are discussed. The first approach can be done by a single person, who revises the genus area after area. The other approach is by a team that revises per infrageneric taxon (preferably a single person per infrageneric group). The two approaches have their positive and negative sides, but both give good results. One problem with both approaches is to keep an overview of a possible infrageneric classification. The latter problem can be tackled by performing phylogenetic analyses based on molecular markers (providing core phylogeny) in combination with morphological, palynological, and anatomical data (providing apomorphies for infrageneric taxa).
\end{abstract}

Published on 30 October 2009

\section{INTRODUCTION}

Revisions of large genera (more than a hundred species) are usually problematical. The major difficulty is to keep an overview, not only to remember all species and their differences (analytical phase), but also to see groupings in the species based on typical characters that may represent possible infrageneric taxa (synthetic phase). The genera Macaranga Thouars (c. 240 spp.) and Mallotus Lour. (c. 110 spp.) are two such large groups. Here an additional difficulty is that the two genera are morphologically quite indistinct. Moreover, they both occur in similar habitats and they responded in the same morphological way to changes in ecological niche (smaller and narrow leaves in primary forest surroundings changing to large and broad leaves in pioneer habitats; Slik et al. 2003). The two genera also show a similar distribution, ranging from Africa to Madagascar and the Mascarenes and from India throughout southeast Asia to the West Pacific and Australia. Typical for both genera is the presence of glandular hairs with a globose to disc-shaped head (here referred to as glandular scales; see Sierra et al. 2006: f. 3d-f) and generally extrafloral nectaries on the upper leaf surface. Furthermore, dioecy is common and the generally dehiscing fruits often carry soft spines. There is only one 'official' difference between the two genera, Macaranga has anthers with 3-4 thecae, and Mallotus only has 2-thecate anthers. All other characters are typical for only part of the genera (e.g., stellate hairs and opposite leaves are present in Mallotus only, but not all species show them; idem for Macaranga where groups of species live in association with ants, and many species have panicles instead of racemes, but the panicles also occur in Mallotus section Mallotus).

The classification of the two genera is also a problem, at the suprageneric level, generic level, as well as the infrageneric classification. The fact that the difference between the two genera is defined by two character states of the same character already indicates that one state is probably plesiomorphic and, therefore, one of the two genera is likely to be a paraphyletic group. This makes it even stranger that the most recent classifications (Webster 1994, Radcliffe-Smith 2001) place the

\footnotetext{
1 Nationaal Herbarium Nederland, Universiteit Leiden branch, P.O. Box 9514,
} 2300 RA Leiden, The Netherlands. two genera in different subtribes (Macaranga in the monothetic Macaranginae and Mallotus with several other genera in the Rottlerinae). Moreover, there are four small genera (Cordemoya Baill., Neotrewia Pax \& K.Hoffm., Octospermum Airy Shaw, and Trewia L.) that are also indistinguishable from Mallotus and their relation to Macaranga and Mallotus had to be re-evaluated too. The infrageneric classifications also posed problems, but we will only touch upon these in this paper.

The purpose of this paper is to discuss three items:

- the pros and cons of two different revisional approaches;

- the benefits of including macromorphological, anatomical, and palynological studies;

- the usefulness of phylogenetic analyses.

\section{REVISIONS}

The ways in which Macaranga and Mallotus were revised are more or less opposite, but both worked well. The two approaches are summarised in Table 1.

Macaranga was mainly revised by a single person, the late Tim Whitmore, with assistance by Stuart Davies. A one-person approach has the advantages that the species concept will be more or less similar for all species, and probably it is easier to keep an overview of all species and possible infrageneric groups. The major disadvantage is that the revision will take a long time with the possibility of an untimely end to the project, because the revisor has to stop prematurely. One of the major problems with revising large genera is the enormous amount of research material. Whitmore handled this problem via an area approach. The whole distribution range was subdivided in more or less natural areas (e.g., the island groups in Malesia) and the species of each area were revised separately. This approach should typically be done by a single person, several persons revising different areas will cause problems with species concepts. There are a few obvious disadvantages to the area approach. Widespread species have to be linked after every area revision. Additional problematic issues may be widespread species that show geographical variation or clines, especially if some of the extremes received different names, then nomenclatoral problems also arise. Related to this is the problem of interpreting widespread species, because the type

(c) 2009 Nationaal Herbarium Nederland

You are free to share - to copy, distribute and transmit the work, under the following conditions:

Attribution: $\quad$ You must attribute the work in the manner specified by the author or licensor (but not in any way that suggests that they endorse you or your use of the work).

Non-commercia:

You must attribute the work in the manner specified

No derivative works: You may not alter, transform, or build upon this work.

For any reuse or distribution, you must make clear to others the license terms of this work, which can be found at http://creativecommons.org/licenses/by-nc-nd/3.0/legalcode. Any of the above conditions can be waived if you get permission from the copyright holder. Nothing in this license impairs or restricts the author's moral rights. 
Table 1 Differences between the two approaches of large revisions. In bold benefits, in italics drawbacks

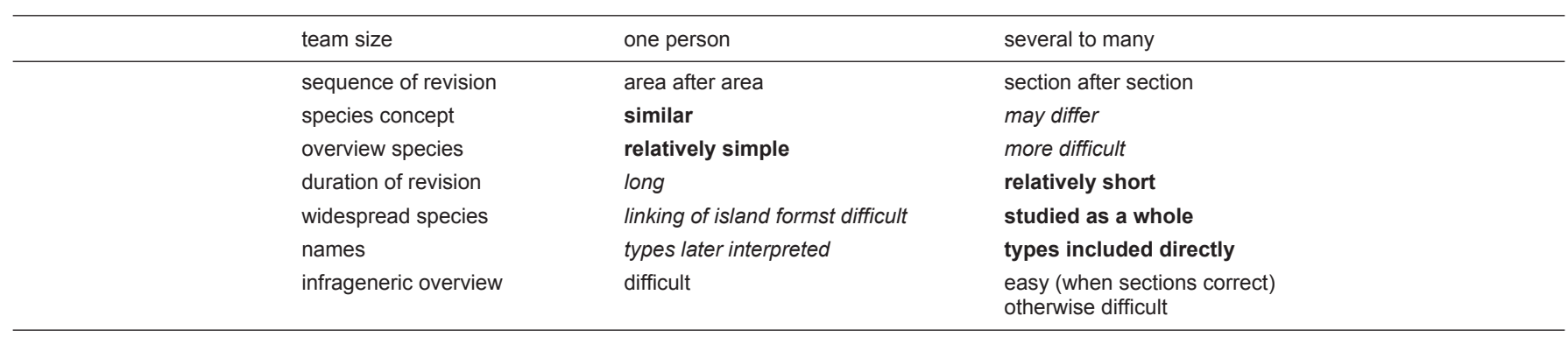

is often not included in the first revisions. This caused problems in a former revision of Mallotus by Airy Shaw, who also used an area approach. Compare the results for Thailand, the same species names in Airy Shaw (1972) and Van Welzen et al. (2000) cover partly different Mallotus species as in Van Welzen et al. (2007). The species concepts are more or less the same, but after studying types from especially Java, it appeared that several entities received wrong names in the 1972 and 2000 revisions. A domino effect occurred because the species only differ in small details: giving one wrong name to a pile automatically resulted in wrong names for other piles. Finally, the area approach may be problematic for keeping an overview of the infrageneric groups. After each area revision the species classification should be rechecked. The problem can be overcome by a separate phylogenetic study (see next chapter).

Mallotus was revised by a team (seven persons). Airy Shaw presented the last infrageneric classification of Mallotus in 1968. He recognised eight sections, which were generally easy to identify. The revisions were made per section, and this has resulted in quite a few publications: Section Polyadenii Pax \& K.Hoffm. (Bollendorff et al. 2000), sections Hancea Pax \& K.Hoffm. and Stylanthus (Rchb.f. \& Zoll.) Pax \& K.Hoffm. (Slik \& Van Welzen 2001), section Philippinenses Pax \& K.Hoffm. (Sierra et al. 2005; formerly section Rottlera (Willd.) Rchb.f. \& Zoll.), section Mallotus (Sierra \& Van Welzen 2005), genus Cordemoya (incl. Mallotus section Oliganthae Airy Shaw: Sierra et al. 2006; presently changed to Hancea, Sierra et al. 2007), section Rottleropsis (incl. section Axenfeldia (Baill.) Pax \& K.Hoffm.: Sierra et al. 2007); and the small genera Trewia, Neotrewia, and Octospermum (Kulju et al. 2007b).

Revisions by teams are best done per section, whereby each section is revised by a single person or, in case of more persons, then with one person in charge. This will best guarantee a constant species concept (e.g., Mallotus kongkandae Welzen \& Phattar. was originally described as a variety mengliangensis C.Y.Wu ex S.M.Hwang of Mallotus philippensis (Lam.) Müll. Arg., but the differences with $M$. philippensis are such that recognition on the species level was warranted; Sierra \& Van Welzen 2006). With widespread species it is easier to obtain an overview of the variation and to interpret type specimens. Another benefit is the much shorter duration of the complete revision. A big drawback is the lack of a complete overview of all species by at least a single person. This makes the construction of identification keys more difficult (though computer programs may help out). Related to this problem is the re-classification of species that were incorrectly placed in, for instance, a section (e.g., five species were incorrectly placed in section Hancea, but were otherwise difficult to place in another section; Van Welzen et al. 2006). Similarly, a lack of an overview on the species level also complicates an infrageneric classification unless the classification on which the revisions were based was correct (see also next chapter). Here too, a phylogenetic study may help to pinpoint the infrageneric taxa.

\section{PHYLOGENY}

One of the problems to be solved was the generic distinction between Macaranga and Mallotus and their relationship with small genera like Cordemoya, Neotrewia, Octospermum, and Trewia. A phylogenetic analysis based on four molecular markers (trnL-F, ITS, ncpGS, phyC) showed that Macaranga is a monophyletic group (Kulju et al. 2007a), while Mallotus appeared to be paraphyletic. The largest part of Mallotus is a sister group of Macaranga. This Mallotus group (Mallotus s.s.) is monophyletic when the genera Neotrewia, Octospermum, and Trewia are included. The (re)transfer of these small genera to Mallotus is published by Kulju et al. (2007b). A problem is that Trewia is an older name than Mallotus, therefore, Kulju \& Van Welzen (2008) wrote a proposal to conserve the name Mallotus against Trewia. A basal group of Mallotus species (sections Oliganthae and Hancea excluding five species: Slik \& Van Welzen 2001, Van Welzen et al. 2006) grouped together with the Madagascar genus Cordemoya and all other Mallotus species of Madagascar and the Mascarene islands, also formerly known as the genus Deuteromallotus. An elegant solution was to transfer the basal Mallotus species to Hancea (Sierra et al. 2006, 2007). This resulted in a monophyletic genus Hancea, sister to the also monophyletic sister groups Mallotus s.s. and Macaranga. The recognisability of the three genera was also increased (see next chapter).

The phylogenetic analysis (Kulju et al. 2007a) and subsequent transfer of species to Hancea (Sierra et al. 2006, 2007) resulted in a well-corroborated infrageneric classification for Hancea, in accordance with the sections already recognised under Mallotus (Fig. 1). Each of these groups have their own typical characters. Two subgenera are recognised (Sierra et al. 2006): Cordemoya (Baill.) S.E.C.Sierra, Kulju \& Welzen (all Indian Ocean taxa) and Hancea (all Asian taxa). The latter subgenus is divided into the sections Hancea Seem. (former Mallotus section Hancea excluding the five deviating species) and monotypic section Oliganthae (Airy Shaw) S.E.C.Sierra, Kulju \& Welzen (former Mallotus section Oliganthae).

The phylogenetic analyses (Kulju et al. 2007a: core phylogeny of the genera based on molecular data; Sierra et al. submitted: detailed phylogeny of Mallotus including morphology and anatomy, f. 1) did not provide sufficient data for infrageneric classifications of Macaranga and Mallotus. The first analysis did not comprise enough species (Kulju et al. 2007a), but the Macaranga part was well resolved and relatively well supported, but this was hardly the case with Mallotus. Also, the second analysis (Sierra et al. submitted), that included many more species and almost for all species morphological data, did not result in a better cladogram for Mallotus, especially the basal branches were badly resolved and certainly not statistically supported. It was remarkable that the inclusion of quantitative morphological and anatomical characters did improve the resolution (though not the support). Still, several sections appeared to be monophyletic. We only mention those of Mallotus, because 


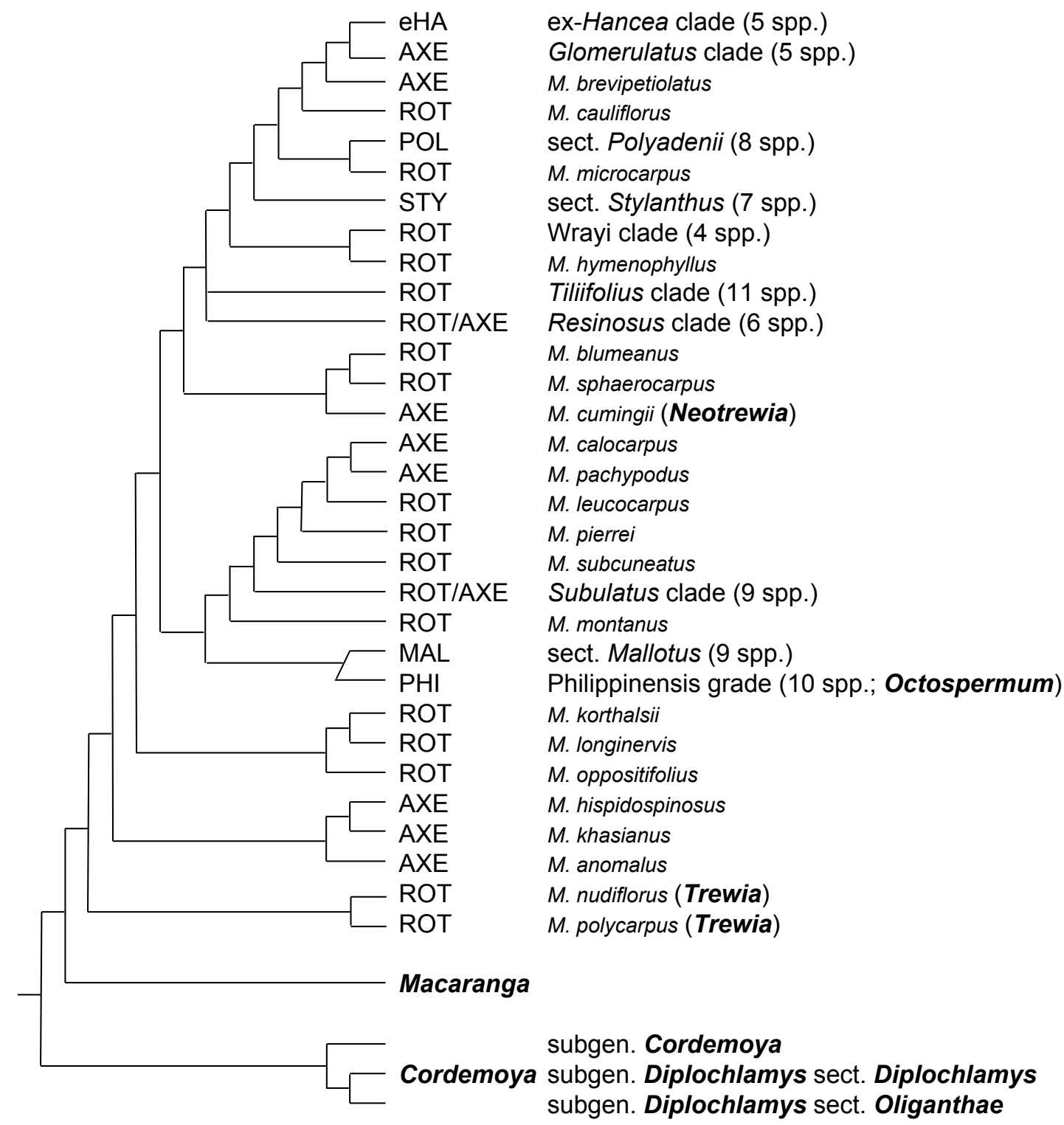

Fig. 1 On of the cladogram of Mallotus (Sierra et al. submitted) based on molecular markers and qualitative and quantitative macromorphological and anatomical characters (quantitative characters used 'as is' with program TNT). Abbreviations indicate the former sections in Mallotus: AXE $=$ Axenfeldia; eHa = ex-Hancea; $\mathrm{MAL}=$ Mallotus; $\mathrm{PHI}=$ Philippinensis; $\mathrm{POL}=$ Polyadenii; ROT = Rottleropsis; $\mathrm{STY}=$ Stylanthus). Added are the infrageneric groups of Hancea (subgen. Cordemoya = Cordemoya s.s. + Deuteromallotus; sect. Hancea = former Mallotus sect. Hancea; sect. Oliganthae= former Mallotus sect. Oliganthae). The monophyletic groups within Mallotus are indicated, just as the Philippinensis grade (diagonal line at base of Hennigian comb); sections Axenfeldia and Rottleropsis s.s. are polyphyletic, when united into Rottleropsis s.I. (Sierra et al. 2007) then the group is paraphyletic.

they were introduced already. Sections Mallotus, Polyadenii, and Stylanthus are monophyletic, while section Philippinensis (= section Rottlera) is paraphyletic and forms a monophyletic grade with section Mallotus. Unfortunately, the largest sections, Axenfeldia and Rottleropsis are polyphyletic (and paraphyletic when united under Rottleropsis s.l.; Sierra et al. 2007), though several small monophyletic groups can be distinguished (see also next chapter).

\section{CHARACTERS}

The phylogenetic analysis of Mallotus was not only based on molecular markers, a palynological (Sierra et al. 2006), and extensive morphological (section revisions) and anatomical data (Fišer et al. in prep.) were included. Especially, the anatomical study proved to be valuable in terms of apomorphies (characteristics) for generic and infrageneric groups, e.g., the glandular scales proved to have many different types.

Cordemoya and Mallotus differ in the ornamentation of the pollen, Cordemoya has an areolate ornamentation with scabrae, and Mallotus a perforate or micro-reticulate ornamentation (also with scabrae), and capitate glandular hairs with multicellular stalks and sessile peltate-stellate hairs with a central cell (see Sierra et al. 2006: f. 3a-c). The opposite, glandular scales (f. 1a), are typical for Macaranga and Mallotus s.s. (few reversals exist). Besides the number of thecae in the anthers, the presence of stellate hairs or stellately bundled hairs is typical for Mallotus s.s.

Several of the sections in Mallotus now have more apomorphies than before (Sierra et al. submitted). Section Mallotus has as apomorphies the presence of paniculate inflorescences, pistillodes, spiny fruits, cork warts, stellate hairs, and no stellately tufted hairs. In the polyphyletic Axenfeldia/Rottleropsis sections several groups are distinct, e.g., the Glomerulatus group with the pistillate inflorescences reduced to glomerules, the Subulatus group with umbel-like pistillate inflorescences, the ex-Hancea clade with the opposite leaves differing in shape, the Wrayi clade (Van Welzen \& Sierra 2006) with extrafloral nectaries on the nerves of the upper leaf surface, etc. 


\section{CONCLUSIONS}

The two scenarios for tackling revisions of large genera have their pros and cons (Table 1), but both give good results. If a rather speedy revision is essential, then a section revision by a team is the way to proceed.

We also indicated the necessity of phylogenetic research (which solved generic boundaries, and indicated the problems with former infrageneric classifications) and good macromorphological, palynological and anatomical research (provided many characters and synapomorphies). These researches will or may slow down the revision work, but the end result is a well-supported classification and good revisions.

Therefore, we do not opt for the quick and dirty approach (which resulted in many wrongly applied names in Mallotus in past revisions), but more for the slow and thorough approach via a team of collaborators.

\section{REFERENCES}

Airy Shaw HK. 1968. Malesian and other Asiatic Euphorbiaceae. Kew Bulletin 21: $379-400$.

Airy Shaw HK. 1972. The Euphorbiaceae of Siam. Kew Bulletin 26: 191363.

Bollendorff SM, Van Welzen PC, Slik JWF. 2000. A taxonomic revision of Mallotus section Polyadenii (Euphorbiaceae). Blumea 45: 319-340.

Fišer Ž, Sierra SEC, Kulju KKM, Van Welzen PC, Baas P. In prep. Leaf anatomy of Mallotus, Cordemoya and Macaranga (Euphorbiaceae s.s.).

Kulju KKM, Sierra SEC, Draisma SGA, Samuel R, Van Welzen PC. 2007a. Molecular phylogeny of Macaranga, Mallotus, and related genera (Euphorbiaceae s.s.): insights from plastid and nuclear DNA sequence data. American Journal of Botany 94: 1726-1743.

Kulju KKM, Sierra SEC, Van Welzen PC. 2007b. Re-shaping Mallotus [Part 2]: inclusion of Neotrewia, Octospermum and Trewia in Mallotus s.s. (Euphorbiaceae s.s.). Blumea 52: 115-136.

Kulju KKM, Van Welzen PC. 2008. Proposal to conserve the name Mallotus against Trevia (“Trewia”) (Euphorbiaceae s.str.). Taxon 57: 1359-1360.

Radcliffe-Smith A. 2001. Genera Euphorbiacearum. Royal Botanic Gardens, Kew.
Sierra SEC, Aparicio M, Gebraad MJH, Kulju KKM, Van Welzen PC. 2007. The morphological range in Mallotus (Euphorbiaceae) and a taxonomic revision of its section Rottleropsis (including Axenfeldia) in Malesia, Thailand and Africa. Blumea 52: 21-113.

Sierra SEC, Aparicio M, Kulju KKM, Fišer Ž, Van Welzen PC, Van der Ham RWJM. 2006. Re-Shaping Mallotus [Part 1]: Expanded circumscription and revision of the genus Cordemoya (Euphorbiaceae). Blumea 51: 519-540.

Sierra SEC, Kulju KKM, Fišer Ž, Aparicio M, Van Welzen PC. Submitted. The phylogeny of Mallotus s.s. (Euphorbiaceae s.s.) inferred from DNA sequence and morphological data. Taxon.

Sierra SEC, Kulju KKM, Veldkamp JF, Van Welzen PC. 2007. Resurrection of Hancea and lectotypification of Adisca (Euphorbiaceae). Blumea 52: 361-366.

Sierra SEC, Van Welzen PC. 2005. A taxonomic revision of Mallotus section Mallotus (Euphorbiaceae) in Malesia. Blumea 50: 249-274.

Sierra SEC, Van Welzen PC. 2006. Mallotus kongkandae (Euphorbiaceae): New record for China. Blumea 51: 365-366.

Sierra SEC, Van Welzen PC, Slik JWF. 2005. A taxonomic revision of Mallotus section Philippinenses (former section Rottlera - Euphorbiaceae) in Malesia and Thailand. Blumea 50: 221-248.

Slik JWF, Keßler PJA, Van Welzen PC. 2003. Macaranga and Mallotus species (Euphorbiaceae) as indicators for disturbance in the mixed lowland dipterocarp forest of East Kalimantan (Indonesia). Ecological Indicators 2: 311-324.

Slik JWF, Van Welzen PC. 2001. A taxonomic revision of Mallotus sections Hancea and Stylanthus (Euphorbiaceae). Blumea 46: 3-66.

Van Welzen PC, Sierra SEC. 2006. The Mallotus wrayi complex (Euphorbiaceae). Blumea 51: 373-388.

Van Welzen PC, Sierra SEC, Gebraad MJH, Kulju KKM. 2006. The distinction of five Mallotus species formerly in section Hancea (Euphorbiaceae). Blumea 51: 367-372.

Van Welzen PC, Sierra SEC, Slik JWF, Bollendorff S. 2007. Mallotus. In: Van Welzen PC, Chayamarit K (eds), Euphorbiaceae (Genera G-Z), Flora of Thailand 8, 2: 384-437. Forest Herbarium, Bangkok.

Van Welzen PC, Slik JWF, Bollendorff SM. 2000. Mallotus. In: Van Welzen PC, Haegens RMAP, Slik JWF, Bollendorff SM, Dressler S, Esser HJ. Checklist of the genera of Thai Euphorbiaceae-I. Thai Forest Bulletin, Botany 28: 93-111.

Webster GL. 1994. Synopsis of the genera and suprageneric taxa of Euphorbiaceae. Annals of the Missouri Botanical Garden 81: 33-144. 